Book Review

\section{The International Law and Practice of Early-Warning and Preventive Diplomacy: The Emerging Global Watch}

\author{
B.G. Ramcharan. Dordrecht, The \\ Netherlands: Martinus Nijhoff \\ Publishers, 1991
}

\section{Reviewed by Howard Adelman}

Terrorists, drug traffickers, environmental abusers, violators of human rights - beware! Now that the Cold War is over, the CIA, MI5 and KGB won't be competing with one another. Istead, they are going to delegate their major responsibilities for security to the United Nations. Henceforth, the U.N. will beinvested with the responsibility of preventing political conflict as well as dealing with humanitarian emergencies. Partnership and cooperation are to replace Cold War posturing and competition. What billions - nay, trillions - spent on weapons and armies could notaccomplish, millions spent on preventive diplomacy will.

There has always been a dream that if we have sufficient knowledge and foresight and marry that knowledge to the proper political weapons, the evil dragons that threaten our civilized system can be destroyed. Now that the evil dragon of communism has vanished into a puff of smoke in Eastern Europe, and transmogrified into a toothy but increasingly decrepit dragon trotted out to puff smoke and fire on its own people at Chinese demonstrations, we can go back to our older mythological dragons as the sources of villainy and the targets of our intelligence services - aliens who take on the shapeand form of our friends and neighbours but are out to terrorize us, witches in disguise offeringdrugs from their cauldrons as if they were sweet apples, giants who trampleour forests, emptyour streams and pollute the environs, and monsters who tie us up and torture and dismember our bodies.
Though this book on early warning systems (EWS) strikes a pose as a method of tracing dragons to their lairs, it is really about humans. Its aim is to develop an early warning system to detect a totally different "menace" - the immanent mass flow of refugees as a result of natural, but primarily, human-made disasters.

There is one key that prevents this from happening. When the major threats to international peace and order come not from the rivalry between different materialist religions, but from the tensions and stresses within autonomous states, the goal of the intelligence has to involve knowledge leading to action, which will intervene in the rights of such states to determine their own destinies, for evil or good. The question is whether the development of such an international intelligence system, and its corollary interventionist political instruments, will pose the same dangers to states' rights to self-determination as the development of the state intelligence systems posed to individual rights. Or is the sacrifice of state autonomy really the final step in preserving and enhancing the protection of fundamental freedoms?

This, and many other issues, are not addressed in Ramcharan's book. He has written a recipe for expanding the U.N. intelligence gathering and early warning system without exploring whether the cake to be baked is good for our health or whether alternative recipes for other cakes might be tastier or healthier, or whether the ingredients are available to bake the cake he has proposed. Ramcharan has written a self-advertisement for the Office for Research and Collection of Information of the United Nations (ORCI). Asadvertisement copy itlacks pizzazz. As program notes, the recipe is iffy. Its great benefit is that we at least have a proposal on the table for debate.

Ramcharan begins by explaining that the conditions are ripe for cake baking. International law has been codified and vastly expanded into a universal system to advance the new world order of values dedicated to protecting individual rights and improving the human condition, instead of remaining a merely regulatory system of rules mutually agreed to by consenting states. Security threats have become both more localized and global. The Colombian drug cartels, the Burmese opium farmers, those whodestroy the forests of Brazil and follow the Western path of industrialization by dumping even more toxins into the environment - these are the new threats to our security. Iraq's suppression of the Kurds cannot and did not remain a local problem. The modern media allow the world to see a crisis as it develops. Contemporary modes of transportation permit a crisis to spill across the world in mass migration flows. Like an erupting volcano spewing fire and ash, theimmediate environment may be turned into a moonscape, but the weather system of the entire earth is affected.

In addition to the internationalization of both threats and the systems of law to counter those threats, the new religiousorder hasinvested in its pope, modestly still called a Secretary-General, the military forces to enforce the peace, the task of keeping the peace and settling disputes. More recently, the U.N. General Assembly has given their Pontiff a mechanism for intelligence gathering to serve those tasks. Since he has already developed a plethora of instruments - fact-finding, observing elections, the use of good offices to settle disputes through diplomacy and a posture as an international leader - the only issue that remains is the recipe's improvement, required to bake a better cake for international order. The system must be strengthened and improved by developing an intelligence gathering system as the key to preventing disputes from blowing up into fullblown crises and to handle any humanitarian emergencies that result.

On what policies and principlesdoes this expansion of early warning depend? First, on the presumption that an EWS is needed. But is there any such agreement? It depends on the purpose for which it is designed. Be- 


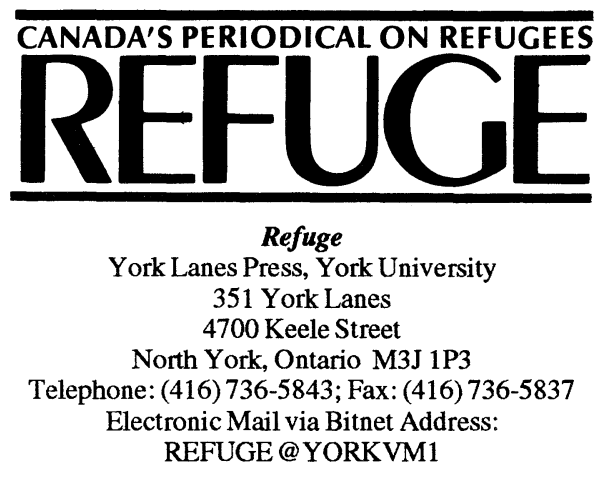

\author{
Postage Paid in Toronto \\ Second Class Mail Registration No. 5512 \\ Return Postage Guaranteed
}

fore we develop an early warning system, we must be clear about whether it is intended to create and enhance a new world order with common universal values or whether its goals are much more modest - to prevent, where possible, and limit the damage when crises occur. Though there may beagreementaboutan EWS for the latter, and Ramcharan frequently posits this modest goal as the function of an EWS - to prevent and mitigate problems - he also implies that an EWS will serve a positive role in creating a system in which the protection of individual rights will be guaranteed.

This ambiguity about the function of an EWS and the presumption of its possible service in creating a new moral order is complemented by the institutional role of the U.N. envisioned as the harmonizer of activities "for the attainment of common ends." The fact that the book lacks any exposition of the well-known inability of the U.N. to even bring some coherence to the many fiefdoms that constitute its organization or create common standards for reporting or sharing information within its own institutional labyrinth, makes any proposal that the U.N. will harmonize the actions of nations seem presumptuous to say the least.

The third policy proposition is the most disingenuous of all. What seems rhetorically winning - avoid cloak and dagger intelligence gathering in favour of sources and methods that are matters of public knowledge - is not only undercut by the suggestion that the results and operations they lead to may be kept from public view, but would also be the basis for limiting involvement of any state, international organization or even the various U.N. agencies themselves. Will the UNHCR share information with a central authority if its sources and analysis are to be made public? Will the International Red Cross? Of course not. They have enough questions about the ethics of sharing with overtly political institutions the information they necessarily gather and the analysis they must make to fulfill their own humanitarian functions, without the threat that their sources and methods will be made public in the naive faith that openness is the best policy. Yet ORCI has no other means of gathering intelligence. These organizations are in the field. They already have extensive sources of information. But if it is to be used not just to put out fires but possibly to create a "higher" value system, and if the sources and methods are to be made public, why would these humanitarian organizations include their reports in an EWS, let alone harmonize their techniques of reporting, measurement and evaluation? And if these U.N. and other international organizations fail to cooperate, why would nations? The result will follow the pattern of state intelligence networks, which begin with high-born goals about centralization and harmonization of information from existing intelligence organizations (the roots of the CIA after the war) and then "discover" that to be effective their own specialized intelligence network is required.

The book does not live up to its own strictures about realism, pragmatism and modesty. It is too U.N.- and Secretary-General-centred a treatise for most of us engaged in the enormously difficult task of sharing information and creating a common signal system, the essential ingredients for an EWS with the most modest of goals. But at least someone has offered a formula for beginning the task of baking.

The first thing that must be recognized is that there will be many recipes, many cooks and many consumers. What we need at this stage is far more modest than anything Ramcharan describes - a common reference system of measurement and taste and a willingness to tell each other what we know in the manner most appropriate to those who have the knowledge. ORCI should envision itself as a contributing cook rather than the master baker.

Howard Adelman is the Director of the Centre for Refugee Studies and Professor of Philosophy at York University. 